\title{
Na fronteira, entre Rui Nunes e Ali Abbasi
}

\section{Diogo Martins}

\author{
Faculdade de Letras do Porto
}

Resumo: Os dois anões de A Boca na Cinza, livro de Rui Nunes, e os dois trolls de Na Fronteira, filme de Ali Abbasi, têm em comum a experiência do limiar entre o humano e o não-humano: são corpos em excesso, amarrados ao peso da sua fisicalidade, motivo da sua exclusão social. Por sua vez, tanto o livro como o filme trabalham as respetivas linguagens num estilo que exacerba as suas potencialidades materiais, como se escrita e imagem fossem dotadas de um corpo. Da colisão entre estes dois corpos faz-se uma reflexão sobre o estranhamento do humano face a si mesmo.

Palavras-chave: escrita, imagem, corpo, monstro

\begin{abstract}
The two dwarves in Rui Nunes's A Boca na Cinza and the two trolls of Ali Abbasi's film On the Border have in common the experience of the threshold between the human and the non-human: they are bodies in excess, tied to the weight of their physicality, the reason for their social exclusion. On the other hand, both the book and the film work their languages in a style that exacerbates their material potentialities, as if writing and image were endowed with a body. From the collision between these two bodies we aim to reflect on the strangeness of the human being in the face of himself.
\end{abstract}

Keywords: writing, image, body, monster 
adereços:

os pés e as mãos,

a murcha máscara

da cara.

Luiza Neto Jorge

[...] não devemos fiar-nos pelo rosto dos homens.

É o seu corpo que nos revela que espécie de animais eles são.

Pär Lagerkvist, 0 Anão

Pegamos num livro distraidamente, supondo que ele irá atravessar a nossa vida com alguma indiferença. E, de súbito, temos a evidência da sua importância: como um corpo.

Eduardo Prado Coelho, 0 Cálculo das Sombras

\section{A Boca na Cinza}

No livro A Boca na Cinza, de Rui Nunes, as personagens da anã e do anão - Sara e Abel - agem como dois irmãos que sabotam a narratividade do livro, quebrando-lhe as linhas, interrompendo a harmonia dos desfechos, abrindo fendas por onde derrapa, até explodir, a possibilidade de se iluminar o sentido - essa ficção salvífica, ou totalidade, que apazigua as ansiedades de quem lê e que, pela leitura, procure mitigar a excessividade sem tréguas da vida. E o sentido, ou a intransigente necessidade em evitar pensar na absoluta ausência de sentido (na vida, na literatura, na humanidade como um todo), é o que move os impulsos diabólicos do protagonista homónimo de um outro romance - $O$ Anão, de Pär Lagerkvist -, quando afirma: "Os homens gostam de se ver reflectidos em espelhos turvos" (Lagerkvist 2013: 176). E porquê? Porque um reflexo esbatido, embaciado, talvez 
estilhaçado por um sem fim de fissuras, preserva o sentido plural desses homens e mulheres, desse todo que é a humanidade. Quanto mais turvo espelho, menos implacável a nitidez: a de que a humanidade, enquanto todo, não existe. Por outro lado, quanto mais turvo o espelho, menor o confronto entre a imagem que esses homens têm de si e a imagem que recusam efetivamente ver. Ou estas outras imagens, imagens de outros: "O seu rosto, mesmo que não lhe façam o retrato, pertence a quem quer que o olhe, isto é, a muita gente" (idem: 34).

Em A Boca na Cinza, uma das personagens anãs esboça este autorretrato à revelia do que um autorretrato, à partida, prometeria mostrar: "sou unicamente olhos que vêem, ouvidos que ouvem, boca que come, dedos que tocam, nariz que cheira, nunca um corpo na sua integridade, quero dizer: um corpo todo, só pedaços dele” (Nunes 2003: 71). Objetos parciais, fragmentos autonomizados, exorbitâncias que, ganhando relevo, apontam obscenamente para si mesmas, mostrando o seu excesso, a sua monstruosidade: um rosto, portanto, que nunca se deixa apanhar num só lance; um corpo, também, que nunca pode conhecer o luxo de passar despercebido no meio da multidão. Se é para um rosto que olhamos e nele vemos, não obstante as suas diferenças e singularidades, a humanidade, como senha imediata com que nos aceitamos enquanto membros de uma espécie comum, então uns "olhos que vêem" ou um "nariz que cheira" nunca formam um rosto: são zonas fronteiriças entre o humano e o inumano, entre nós e os outros. E quando se pisa esse risco, é a nossa própria humanidade - essa potentíssima "máquina antropológica", segundo Giorgio Agamben - que se põe em risco: a máquina falha no ofício de representar, um rosto permanece irreconhecível. A imagem nua da desagregação retém-nos numa imobilidade atroz, como se nos impedisse de desviar os olhos de algo para o qual nos custa olhar. Como num retrato feito por Francis Bacon: um pedaço de carne a olhar para nós.

hoje, você tem uma pobreza que me olha, me bate, me massacra, ao menos, quando estou bêbada, as frases desfazem-se e as palavras são ilhas claras, torno-me então uma palavra só, que se repete, vejo a sua boca, mano, a separar as palavras que me diz, até me dizer letra a letra e eu ficar irreconhecível, com o nome desfeito, com o corpo a desfazer-se, os seus olhos, mano, vêem-me bocado a bocado, sinto-me um talhante que esquarteja a carcaça de um boi, pendurada no gancho. (idem: 108) 
Antes, no mesmo livro, já se antevia isto: que "bocado a bocado não se faz um corpo, mas uma deflagração" (idem, 65). Uma deflagração é uma das possibilidades de se dar a ver o que é descontínuo, o que sai fora dos eixos, a força que desorienta o olhar. Como uma imagem que nunca se fixa, atirando-nos para esse intervalo de pânico que é o de não saber identificar a origem de um ruído a meio da noite, saber se ainda se tem pé sobre o chão, ou o medo de olhar para debaixo da cama: não porque acreditemos na existência de monstros, mas porque a existência, por si só, excede as medidas de um tão extemporâneo desassossego.

Assim, uma deflagração acontece, também, na própria ideia do romance enquanto género literário, que deixa de ser operativo num autor como Rui Nunes. A expectativa de uma história a ser (bem) contada, num arco temporal que nos explique tudo, com heróis e vilões bem discriminados, sai aqui violentamente agredida. Por exemplo: se o mesmo par de anões consegue amolecer-nos o coração pelo desamparo de que se sentem vítimas - “o terror é esse, mano, nunca nos abandonaram, nunca nos amaram para nos poderem abandonar, voltaram-nos simplesmente as costas" (idem: 130) -, a mesma dupla não se deixa vencer pelo excesso de zelo alheio e restantes bons sentimentos, como se a deformidade física assegurasse, em jeito de prémio de consolação atribuído a terceiros, uma alma incorruptível, destinatária de todas as bem-aventuranças. Pelo contrário, estes anões mostram-se sórdidos, diabretes mesquinhos, tão sacanas quanto o mundo, que entra num desmiolado alvoroço de cada vez que é chamado a aveludar a repulsa:

como estão? pergunta-lhes o empregado, ao acompanhá-los à mesa do costume, [...] o empregado vai e vem carregando listas telefónicas que empilha nos assentos das cadeiras, [...] eles observam-no e movem a cabeça, para baixo e para cima, num sentimento contente, eis um bom trabalho, depois, Sara ergue a mão: chega, e o empregado fica em sentido, a seu lado, muito direito, a sorrir, ela pensa: sorriso de merda, o deste sacana, goza connosco a fingir que nos respeita, vai para casa e diz: os filhos da puta dos anões foram hoje jantar ao restaurante, mas agora é todo salamaleques, não podemos acreditar nos pobres, o que eles querem, o que eles querem sei eu. (idem: 58-9)

Mas violência e agressão, aqui, não se exibem necessariamente pela desfaçatez 
lexical e pelo pouco tento na língua; na verdade, o uso de palavras como "puta", "caralho" ou "punheta" presta-se mais a um diabólico e gratuito regozijo do que propriamente ao escândalo - mas não subestimemos o poder de uma imagem destas ainda nos chocar, forma íntima de um texto se colar, ofegante, aos ritmos profundos do nosso corpo:

- está a ouvir-me? mano, quando começará a ouvir-me?

- quando a mana tiver caralho e não mamas, quando a mana bater uma punheta, quando lhe vier este cheiro a urina, destes rins que já não moem este sangue,

(pausa)

- vou tomar um comprimido, mana, para que as suas palavras se afastem de mim, eu não gosto delas porque são as de um pobre, sabe, e as palavras dos pobres batem-nos nos lábios e ferem-nos, são coisas, amo-te não é uma coisa, mas a mana não sabe [...] (idem: 130)

Se, por um lado, em passagens como a que acima se transcreveu, as alusões ao sexo, como forma exponencialmente íntima de contacto entre humanos, são alvo de "uma total deserotização", segundo Manuel de Freitas (de Freitas 2012: 118), despojando a relação sexual de toda e qualquer "beleza, elevação ou gozo transgressor" (ibidem), por outro lado, a um outro nível, o verbo faz-se carne nestes excursos mais imoderados: a linguagem devém um meio de escapar à ambiguidade desrealizante do mundo. Procura-se designar as coisas com a nitidez necessária para que elas possam fulgir como corpos reais, formas onde a memória e os afetos se inscrevem, permitindo às personagens a ilusão temporária de "uma vida como as outras": "os palavrões atam-me a um lugar, são uma espécie de âncoras, quando tenho medo digo um palavrão e tudo fica estável, o palavrão torna-me uma pessoa como as outras, numa vida como as outras, é uma máscara” (Nunes 2003: 106).

Violência, atrito, deflagração: mais do que um léxico corrosivo, é na sintaxe que Rui Nunes inflige golpes, abre buracos e fissuras. Forma e deforma, faz e desfaz. A frase esquivase à pretensão de descrever, de narrar. 0 autor leva a frase a um limite, que é quando ela, de súbito, não se completa, não se liga a nada, não deixa que um sentido se aclare e nos acalme, como os amantes que se deitam "no feno dos romances", segundo a imagem sedutora de $\mathrm{Al}$ Berto, "para que a manhã não solte o ciúme / e de novo nos obrigue a fugir" (Berto 2004: 
111).

Mas a fuga, em Rui Nunes, não é uma consequência: é a condição possível, ou a condição primeira, para que a literatura aconteça. E é ao serviço dessa fuga constante, dessa expulsão a que a linguagem nos obriga para percebermos o poder terrível que ela segrega, que a sintaxe oblíqua em Rui Nunes transforma cada frase, cada bloco de texto, num pequeno monstro deslocado: porque "as dores são animais exasperados" (Nunes 2003: 75), os fragmentos textuais leem-se como se leriam os uivos, os gritos, "o ruído da língua no pelo" (idem: 101), o som dos objetos a estatelarem-se no chão. Para tal, a materialidade híbrida do livro - cortes, fragmentos, polifonia de vozes, negritos e itálicos - vai ao encontro das duas razões para o dispositivo que Eduardo Prado Coelho intersetara na escrita de Rui Nunes (neste caso, a respeito de um outro livro seu, Que sinos dobram por aqueles que morrem como gado?, mas cujo dispositivo nos parece igualmente atuante em $A$ Boca na Cinza, apesar das diferenças estruturais entre este par de livros):

[...] em primeiro lugar, porque era preciso um dispositivo que funcionasse como dique para que o peso da dor não acabasse por esmagar, e tornar literariamente inabordável, a arquitectura do próprio livro; em segundo lugar, porque, no processo de esvaziamento do mundo para que a obra nos convoca, manter o entrechoque de vozes que se apelam no emparedamento das suas diferenças é ainda uma técnica de suspensão do caos, e manobra de sobrevivência. (Coelho 1997: 288)

Incapaz de representar o irrepresentável, a linguagem soluça, gagueja, tosse. Emite sons, grunhidos, arranha o ar. Ou não (se) diz. Por outras palavras (a manha desta expressão: outras palavras continuam a ser palavras, palavras apesar de tudo, e apesar de tudo é o que nos sobra para arrancar ao dizível esse lastro do indizível): "as palavras ajudam-nos a viver, mesmo a viver a morte, mas não a morrer" (Nunes 2003: 101).

Se é, portanto, na sintaxe que as feridas do texto adquirem a sua forma visível, as rugas e estrias que impedem a harmonia de se aplanar num texto, alisando-o, esclarecido e dominado pelo poder (poder de interpretar, poder de entender, poder de dar a transparência às coisas sob a forma de nomes, nomes para nos sentirmos seguros e imunizados contra o poder anónimo e misterioso das próprias coisas...), não deixa de haver 
pequenas ilhas semânticas no texto ("uma técnica de suspensão do caos", uma "manobra de sobrevivência", dizia Eduardo Prado Coelho) - onde essa mesma harmonia, porém, acabará por ir dar à costa, como um náufrago, para logo ser denunciada: "a harmonia apaga-nos, apaga, afaga, isto é, lima-nos até sermos uma nota consonante, uma raiva que outros lábios possam dizer" (idem: 129). Repare-se neste jogo de palavras: “apaga, afaga”. A harmonia, sendo dócil, é perversa: extingue as diferenças num caldo homogéneo. Os pequenos monstros perdem, assim, direito à dignidade de serem o que são - a virtude de serem (sermos), nada mais, nada menos, do que erros errantes, anomalias bípedes com polegar oponível, tão mutantes quanto o Wolverine, discípulos involuntários da metamorfose: "somos doentes, nascemos doentes, nem sei bem que outra doença poderá surgir, nesta, para nos matar, ou desta, a nossa vida são doenças que se vão sucedendo, a nossa história é a da mutação de uma doença" (idem: 79).

\section{Na fronteira}

A ser assim, que fazer quando isto arde?

Não é conclusiva (nem conviria que o fosse), mas a resolução que se segue, proposta por Golgona Anghel, parece funcional com a "alegria de uma deriva", na expressão de Rui Nunes (desta vez, em Suíte e Fúria, 2018). A deriva, aqui, intervém da mesma forma que a doença: são dois estados interruptores, um modo de se "perder o rosto" (Deleuze), de abrir linhas de fuga na língua do poder ("fascista", chamou-lhe Barthes: "porque o fascismo não consiste em impedir de dizer, mas em obrigar a dizer", Barthes 1988: 16). Em A Forma Custa Caro (2018), a autora conclui:

\footnotetext{
Não adianta tentarmos domesticar os rebeldes, integrar os excluídos, incluir a margem, pois estamos todos no mesmo barco. Não podemos continuar a tratar a excepção como algo de que precisamos fugir. Somos todos pretos, ciganos, judeus, palestinianos. Vivemos todos fora de sítio. Falamos todos numa língua estrangeira. A excepção é a nossa regra. Este mundo, certamente, é um lugar inóspito. Mas isso não significa que tenhamos de aceitar a inospitabilidade com resignação. Não podemos seguir reproduzindo as suas caras sinistras, os seus lugares agrestes como se precisássemos de ser fiéis ao nosso desastre, como se fosse necessário «adequar» a arte a este asilo planetário e assim fazer
} 
ressoar os passos dos doentes nos seus corredores. (Anghel 2018: 57)

Somos todos mutantes, a exceção é a nossa regra (e há, a propósito, um curiosíssimo livro de um professor de biologia evolucionista que explora muito de perto, em clave quase literal, a fábrica de prodígios que os nossos genes põem a funcionar: o autor, Armand Marie Leroi; o livro intitula-se, precisamente, Mutantes: Forma, Variações e Erros do Corpo Humano, 2009).

Vivemos todos fora de sítio. Segundo Byung-Chul Han, “O romance de Albert Camus $O$ Estrangeiro descreve a estrangeiridade como sentimento ôntico e existencial fundamental. $\mathrm{O}$ homem é um estranho no mundo, um estranho entre os homens e também um estranho para si mesmo" (Han 2018: 47). E nesta desterritorialização, se a geografia conta muito, os despiques ontológicos custam tantas vezes numa dor silenciosa (pior: silenciada), tantas vezes incapaz, até, de se reconhecer como dor. E é neste ponto que um filme como Na Fronteira (título original: Gräns, 2018), de Ali Abbasi, coloca in extremis o lado irredutível da diferença, ou o que há de implacavelmente ostensivo no monstro, na monstruosidade, no excesso de ser do próprio ser. De todos os seres (somos todos mutantes...), mas, primeiro, de alguns seres: o par de anões de Rui Nunes e, agora, os dois trolls deste conto de fadas para adultos, Tina e Vore.

Em entrevista ao Ípsilon, comenta o realizador:

Se eu andar na rua em Copenhaga as pessoas olham para mim. É um facto. Mas seria a mesma coisa se eu fosse ou muito alto ou demasiado baixo. Sinto-me outsider. É muito fácil, para mim, relacionar-me com isso. Mas penso que depois de ver Na Fronteira a maioria das pessoas sentiu que não pertence. Ninguém se sente incluído. Ainda tenho de encontrar alguém que se sinta incluído. Até o milionário se sente invejado. (entrevista ao ípsilon, 7 de março de 2019, em linha)

E conclui:

Não é preciso haver grandes problemas de identidade, política ou de género, para nos sentirmos marginalizados. Há hoje uma espécie de tribalismo na cultura de que não gosto. A ideia de que só um africano que vive em Inglaterra é que pode falar de um africano que vive em Inglaterra. A minha 
experiência é que aquilo que exprimimos, as nossas habilidades e capacidades, são maiores do que a nossa identidade. (ibidem)

Na verdade, no princípio do filme, somos levados a crer (assim como a própria personagem) que Tina é um ser humano, tão estranho como nós. Funcionária aduaneira, o seu dom é ter uma aptidão especial para detetar a culpa, a vergonha e o medo nas pessoas, o que a torna um elemento eficaz na colaboração com a polícia (o seu faro leva-a, por exemplo, a desmantelar uma rede de pedofilia). 0 modo como esse dom inato se visibiliza faz-se no limiar entre o humano e o outro, esse inclassificável, o monstro: um rosto deformado, com excesso de pelos e dentes protuberantes, figura entroncada e ameaçadora. Tina apresenta-se-nos, assim, como uma mulher. "Feia, estranha e com uma anomalia cromossomática", diz-nos. Os cães ladram-lhe quando ela passa, os miúdos chamam-lhe "cabra feiosa". Se é verdade que "o mundo perde cada vez mais a negatividade do contrário" (Han 2018: 51), as feições de Tina são radicalmente liminares para que a situação se reverta: o seu maior obstáculo na contemporaneidade é o imperativo da "positividade do idêntico", segundo Byung-Chul Han. Logo, longe de despertar curiosidade ou fascínio, preliminares da empatia, a negatividade de Tina provoca medo, repulsa e desdém.

“Até que conhece Vore.” A síntese é de Vasco Câmara, que entrevistou o realizador:

[Vore] É em tudo igual a ela, o mesmo rosto e o mesmo corpo. É seu semelhante, menos numa coisa: Vore sabe quem é. É um troll, criatura do mundo mágico, do folclore escandinavo, e surge com um plano de vingança sobre os humanos que no passado espezinharam a sua espécie. A sua espécie e a espécie de Tina, e ela vê assim revelada a sua condição que tomara por desordem de cromossomas e explicadas as dificuldades sexuais. (entrevista ao ípsilon, 7 de março de 2019, em linha)

Segundo Vasco Câmara, Na Fronteira é um filme com cheiro. É pelo olfato, afirma o crítico, que vemos o filme. Há nele uma cena específica - a cena sexual entre Tina e Vore, no meio da floresta - que exacerba, precisamente, as virtudes sensoriais das personagens: 0 cio, a saliva, o musgo amarfanhado sob os dedos, sujos de terra, os dois corpos montados um no outro, o seu peso, os grunhidos de êxtase. São dois animais que experienciam o prazer, sem o filtro da civilização, alinhados com os ritmos do cosmos: a noite, a natureza, a 
humidade do ar. Como numa cena pagã, ou primordial, explica o realizador que "é nessa cena que se revela que eles não são humanos" (ibidem).

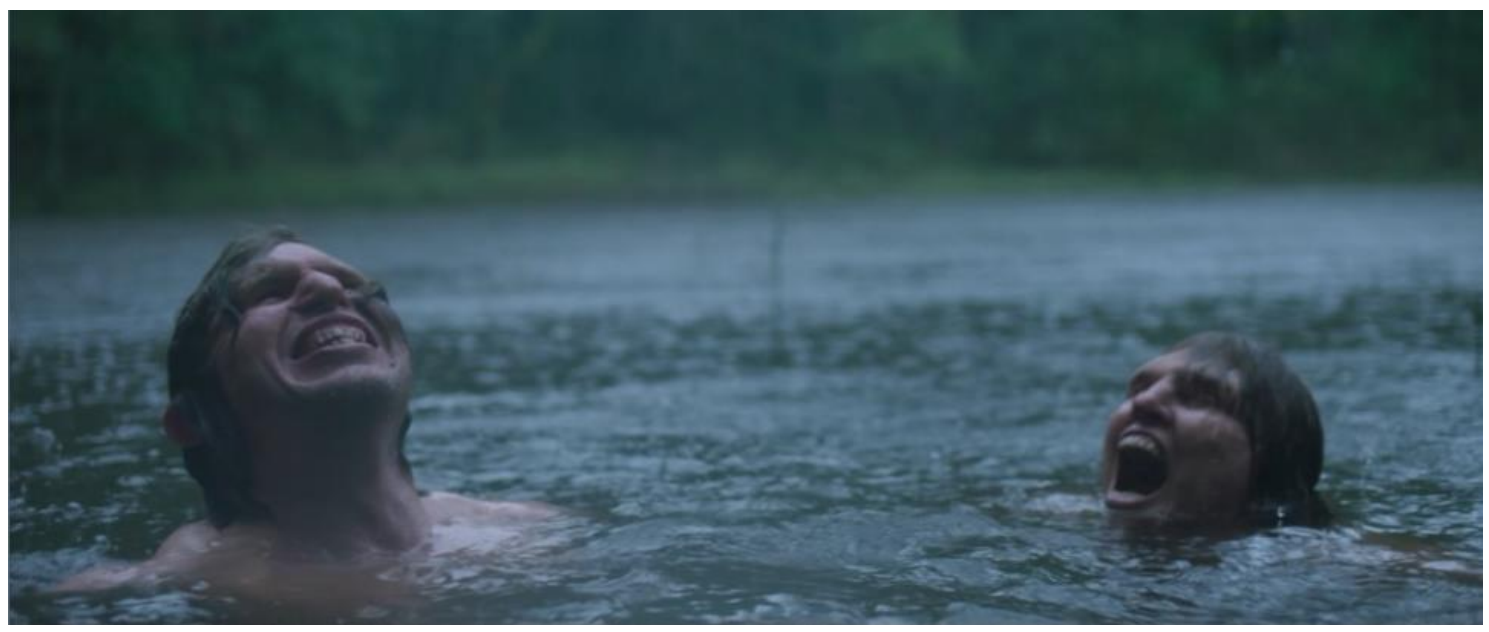

E neste trânsito entre as criaturas do filme e os anões do livro, é tentador estender esta última frase de Ali Abbasi como se a continuássemos com o texto de Rui Nunes, experimentando-se assim, aí, corpo a corpo, o lugar e o tempo que informam a alteridade, recorporalizando-a, inscrevendo-a na carne do mundo, como membros de uma comunidade real. Podemos, assim, atrever-nos a ler o excerto seguinte como se de um diário de Tina se tratasse:

estou sempre a fugir mas não para sítios amáveis, também não os há, o passado repele-me, a minha história é uma agressão que carrego às costas, o presente são três letras atarracadas, numa palavra atarracada, com um peso terminal que a desequilibra e a não deixa mover-se, como uma âncora, essa palavra reproduz-me, na sua quase simetria, cabeça para um lado e pés para outro, estes pés que me cansam, me deixam a arfar quando me mexo, me puxam para a terra, o passeio, a rua, o canteiro, essa palavra, dita, é o meu corpo sob a forma de som, escrita, é um nó na folha, quase informe, pouco nítida, fechada em si numa teimosia, essa palavra é um tiro baço, num poço, com a água estagnada, no fundo, cheia de limos, essa palavra não mata, como todas, salva, mas deforma o texto, o ar, o ouvido que a recebe, essa palavra esclarece a minha deformação, sim, porque há palavras com uma luz malevolente. (Nunes 2003: 90-1) 


\section{0 corpo como último refúgio}

Se $A$ Boca na Cinza não destoa na bibliografia de Rui Nunes quanto a disrupções e dissensões na lógica da narrativa, exacerbando a natureza inclassificável deste e doutros livros do autor, já o filme Na Fronteira tem muito pouco de disruptivo ou dissensual na sua sintaxe. Cumpre-se, de facto, como uma narrativa fílmica bastante convencional, encadeada do princípio ao fim, terminando, inclusive, com a personagem feminina amparando um bebé troll. Ao contrário dos livros de Rui Nunes, o filme de Ali Abbasi promete, ainda, um futuro: o mundo ainda não acabou, ainda há possibilidade para a esperança. 0 estado selvagem com o qual Tina parece ter-se reconciliado (vemo-la, no final, desgrenhada, a deambular pelo bosque, sem qualquer zelo pela higiene, mais brutificada, mastigando larvas) não determina um fim irreversível ou fatídico, mas embala a promessa, no mesmo gesto que protege o bebé, de um porvir, de uma continuidade para a sua espécie. Há, por assim dizer, um sentido que redime tudo isto: a solidão, o desprezo alheio, a dor da diferença. Um sentido intrínseco a esse porvir que o desfecho entrevê.

Não foi, portanto, objetivo deste ensaio pensar as contiguidades entre o livro e o filme enquanto possíveis continuidades, a título quase especular: como se a sintaxe descontínua de $\mathrm{A}$ Boca na Cinza tivesse aspetos em comum com a sintaxe fílmica de $\mathrm{Na}$ Fronteira. A esse nível comparatístico, o exercício frustra. A questão é outra: é a de as imagens do filme "terem cheiro", como assinalou Vasco Câmara, da mesma maneira que as palavras de Rui Nunes adquirem uma consistência ferozmente matéria, com peso e medida - e, por isso, como assinalou Manuel de Freitas, “A Boca na Cinza é um daqueles raros livros que tende a congelar qualquer apreciação ou disposição crítica; aceitamo-lo ou rejeitamo-lo como se de um corpo, de uma prótese ou de um alimento se tratasse" (de Freitas 2012: 117).

Tanto no filme como no livro, há uma excessividade: dos corpos, da sua atuação no mundo, do que significa existir sendo aquilo que se é, essa insanável clivagem. E tendo em conta que a figura do outro não escapa à sua corporalidade excessiva - o par de anões no livro, o par de trolls no filme -, é interessante pensar essa morfologia facial em clave elegíaca: como se pela excessividade deste conjunto de rostos pudéssemos fazer o luto pela 
nossa perda da face. Situação anacrónica: em plena era da revolução digital, que faz proliferar rostos, faces ou caras, numa multiplicidade desmedida, um par de caras disformes estanca por momentos essa voragem, institui-se como uma pausa terrível num tempo que não tolera interrupções, errâncias ou desvios. Uma pausa terrível porque exige que se dê tempo ao tempo: silêncio, dúvida, contacto, assombro. 0 contrário da continuidade do idêntico, que Byung-Chul Han denuncia como a lógica da cultura neoliberal, cuja produtividade, eficácia e otimização, para poderem funcionar de forma desinibida, requerem a exclusão de tudo o que suscite uma demora contemplativa, de tudo o que levante a mais leve resistência. Em síntese: a exclusão de tudo o que não se limite a "funcionar ou fracassar" (Han 2018: 34). Nesse sentido, as formas pesadas de Tina e Vore, assim como os corpos de Sara e Abel, com a sua negatividade irredutível, constituem uma oposição radical a uma ordem que apenas floresce sob uma positividade opressiva, isto é, sem sombra, sem vazio, sem intervalo, sem opacidade. 0 que é o mesmo que dizer: sem corpo.

O imperativo de transparência elimina toda a ausência de visão e todo o oco informativo, deixando tudo à mercê de uma visibilidade total. Leva ao desaparecimento de todos os espaços de recuo e de proteção. 0 que faz com que tudo assuma para nós uma proximidade ameaçadora. Nada nos serve de ecrã protetor. Nós mesmos não somos mais do que passagens no meio da interconexão global. A transparência e a hipercomunicação despojam-nos de toda a intimidade protetora. Mais ainda, renunciamos a ela voluntariamente, expondo-nos ao mesmo tempo a redes digitais que nos penetram, nos iluminam e nos perfuram. A sobre-exposição e a desproteção digitais geram um medo latente que não se explica em função da negatividade do outro, mas do excesso de positividade. No inferno transparente do idêntico, o medo não falta. 0 que faz medo é, justamente, essa embriaguez causada pelo idêntico e que se torna cada vez mais intensa. (idem: 46)

A ordem digital provoca uma descorporalização crescente do mundo. Há hoje cada vez menos comunicação entre corpos. A ordem digital elimina também os corpos que se nos contrapõem privando as coisas da sua densidade material, da sua massa, do seu peso específico, da sua vida própria e do seu tempo próprio, e deixando-as disponíveis a todo o momento. [...] Não chega resistência alguma da sua parte. (idem: 53-4) 
Perante isto, recupere-se o final do último excerto de $A$ Boca na Cinza aqui citado: “[...] essa palavra esclarece a minha deformação, sim, porque há palavras com uma luz malevolente" (Nunes 2003: 91). Uma palavra esclarecedora, que visa sossegar uma dúvida, aliviar alguém de uma inquietação provisória, possui "uma luz malevolente". Palavras malevolentes destituem um corpo do seu segredo, do direito a permanecer secreto, a ter uma intimidade. A ficção de um lado avesso, um interior como abrigo. Uma luz malevolente é uma luz totalitária, "uma pálpebra sem olho", segundo Jean-Luc Nancy (2000): um olho que nunca dá descanso à visão, que tudo absorve, indiscriminadamente, incapaz de curtocircuitar o tempo. É a visão panótica de Bentham por excelência, que Byung-Chul Han estende à lógica soberana da comunicação digital, à qual nem “os pensamentos [...] passam desapercebidos" (Han 2018: 62). Paradoxo perverso: "Os ocupantes do panótico digital não se sentem observados, quer dizer, não se sentem vigiados. Sentem-se livres e despem-se voluntariamente. 0 panótico digital não restringe a liberdade, explora-a" (ibidem). Uma luz obsolescente não permite o rasto, nem a aura, a negatividade imanente ao outro, ao diferente, ao enigma. Daí ser pornográfica. Daí descorporalizar o corpo. Daí, por fim, Sara, Abel, Tina e Vore estarem a mais neste mundo.

Posto isto, o subterfúgio possível: a busca de uma obscuridade luminosa, de uma luz negra. Como sugere Rui Nunes em Suíte e Fúria, “[...] na dor mais extrema, aquilo que resta, se alguma coisa resta, é o corpo, refúgio dos sem-ninguém, abrigados nele, enrolados nele, mesmo velho, mesmo feio, não sempre, só às vezes, mas a vida é só às vezes" (Nunes 2018: 53). Parece não haver fuga possível ao corpo: mesmo estando a mais no coração da linguagem, segundo Jean-Juc Nancy - "Talvez corpo seja a palavra por excelência sem emprego. A palavra a mais em qualquer linguagem” (Nancy 2000: 21) -, é no corpo, através dele, em seu nome, que acontecem as intermitências da vida, esse "só às vezes" por onde as personagens de $A$ Boca na Cinza e Na Fronteira se realizam na sua imanência, no esplendor de serem restos absolutos, a-significantes, sem genealogia, taxonomia ou hierarquia que os aprisione. Nesse "só às vezes", conhecem a liberdade.

A partir daqui, sob o signo desta liberdade, enquanto irrupção do singular (do corporal) no inferno do idêntico, há toda uma constelação de conceitos que podem dar 
alguma ordem ao caos (mas sem que esse mesmo caos se dissipe; porque é necessário um certo caos - a tal deriva, a tal doença - para que a realidade não se cristalize, irradiando sempre uma diferença, uma abertura, a possibilidade do espanto).

Sob o signo, por exemplo, do "contemporâneo", de Giorgio Agamben: no excesso de luz, procurar onde a noite ainda seja livre de escurecer, onde um corpo ainda faça sombra, e aí, nessa noite ou sombra do presente, captar o que nos interpela e, em simultâneo, "se afasta infinitamente de nós" (Agamben 2010: 24). Sob o signo do "trapeiro", de Walter Benjamin: o historiador que, escovando a História a contrapelo, olha com minúcia até para os pormenores mais ínfimos, o refugo, a escória, com as suas impurezas e detritos, reconhecendo em todos os acontecimentos, grandes ou pequenos, que "nada do que alguma vez adveio deve ser considerado como perdido para a história" (Benjamin apud DidiHuberman 2017: 130). Deste modo, se “a história [se] decompõe em imagens, não em histórias" (Benjamin 2019: 606), se uma "imagem dialéctica aparece como um relâmpago", “como uma imagem de brilho súbito no Agora da possibilidade de conhecimento" (idem: 603), podemos entrever em A Boca na Cinza muitos desses relâmpagos, muitos desses resíduos aos quais as duas personagens dão uma atenção privilegiada, como pequenos guardiões de sobrevivências e anacronismos, num mundo que se sabe de antemão estar destinado à ruína. Melhor: que recomeça sempre pela ruína, incapaz de se reconciliar com ela, incapaz de a esconjurar.

(porque vemos o que outros não vêem: as paredes junto ao chão, o papel a esgarçar-se no rodapé, a madeira que apodreceu, se tornou fina e quebradiça, e que os dedos tocam com tanto cuidado, não se vá partir ou esburacar, o pó acumulado nos cantos, as baratas de um vermelho-acastanhado transparente que param expectantes à entrada dos seus esconderijos, entre o nosso mundo e o dos outros há a distância de uns centímetros e no entanto são tão diferentes, as suas vozes parecem um tecto das nossas, a sua sombra cobre-nos totalmente) (Nunes 2003: 124)

O que há, então, de importante a reter sobre um pedaço de madeira apodrecida? Ou nesse pó acumulado nos cantos? Não necessariamente a madeira ou o pó, não necessariamente a metáfora ou a alegoria que daí seja possível retirar, como réplica 
involuntária de sermos animais pensantes, desesperados por dar (de novo) um sentido às coisas, como quem deposita flores na campa de Deus. Não esta ou aquela coisa, mas o movimento que as anima, mais o movimento que nos implica nelas, nessa madeira ou nesse pó: as tensões que, de súbito, se acendem, nos acendem, só pelo simples facto de aí termos reparado, de aí se ter intervalado um olhar, uma dúvida, uma promessa de alegria. Este olhar minucioso dos anões - que encontra um paralelismo na atenção demorada de Tina, no início do filme, sobre um pequeno inseto numa planta ou, no final, sobre um verme escondido na casca da árvore, que Tina decide levar à boca e lentamente saborear - parece quadrar-se com o que Peter Sloterdijk designa como uma fisionómica filosófica, que "segue a ideia de uma segunda linguagem sem fala", pensável "na esfera do faro e da orientação animal", agindo assim "contra o veneno da devastação dos sentidos, que é o preço a pagar pelo nosso progresso civilizacional" (Sloterdijk 2011: 189). Este complexo sistema de reflexão psicossomática não pode, por isso, prescindir do corpo, da sua veemência sensorial. Pelo contrário: ressignifica o corpo, convoca-o em todo o seu esplendor orgânico e, por arrasto, contagia as suas proximidades, por mais banais ou inapeláveis que sejam.

Enquanto o processo de civilização, cuja peça central é constituída pelas ciências, nos ensina a pôr os seres humanos e coisas à distância, de forma que as temos diante de nós como 'objectos', o sentido fisionómico dá-nos uma chave para tudo o que revela a proximidade do mundo envolvente. 0 seu segredo é intimidade, e não distanciação; propicia um saber das coisas que não é objectivo mas convivial. Sabe que tudo tem uma forma e que cada forma nos fala várias vezes; a pele pode ouvir, os ouvidos podem ver, os olhos distinguem o quente e o frio. 0 sentido fisionómico presta atenção às tensões das formas e, vizinho das coisas, espia o seu rumorejar expressivo. (idem, 189-190)

Insista-se: Sara e Abel são anões, são os excluídos da vida, mas ainda assim retiram dessa exclusão uma insolência vital: "vemos o que outros não vêem", avizinham-se das coisas baixas, das contingências e marginalidades que os outros recusam. Trata-se, então, de uma situação-limite, começando por ser o limite do olhar, que se foca obsessivamente nos pormenores em detrimento da paisagem, essa ilusão de uma totalidade perfeitamente coesa. A este propósito, atente-se nas palavras de Rui Nunes, numa entrevista concedida a 


\section{Maria da Conceição Caleiro:}

Eu, em miúdo, gostava de aproximar os olhos das coisas, não para as ver mas para ver as pequenas coisas que estão nas coisas, e isso fascinava-me e ainda hoje me fascina. Esse é o limite da minha visão. Impede-me de ver a paisagem e leva-me às coisas mais pobres, as que estão sempre a escapar, que não se mostram. Só se mostram a um olhar pobre que é o meu. (Nunes apud Caleiro 2013: 59)

Por sua vez, esse zoom operado sobre os objetos revela a implacável iminência da morte: a morte que mais ninguém quer reconhecer, a morte que se dilui e se esconde na figuração ampla da paisagem. A morte, por fim, que os dois anões perscrutam e de que são a imagem ostensiva: dois seres que carregam em si a diferença, incapazes de se subtrair a esse fardo, tal é o modo como este se (con)funde com os seus corpos. Eles veem o que os outros não veem - ou se recusam a ver. E essa condição-limite não lhes é perdoada.

As coisas, quando nós aproximamos os olhos delas, mostram que estão a morrer. Se eu aproximar os olhos da pele de uma pessoa que eu ache lindíssima, a pele mostra que a pessoa está a morrer, a pele mostra os poros, os pelos, as borbulhas... Se eu visse muito bem, até veria os ácaros, a pessoa morre na aproximação, surge outra coisa que também se propõe a uma morte muito rápida. Só os mortos é que demoram imenso a morrer. (ibidem)

As paredes junto ao chão, o papel a esgarçar-se no rodapé, a madeira que apodreceu que é o mundo, senão, uma imensa vanitas em denegação? (E poderá "uma imensa vanitas em denegação" equivaler ao que hoje se designa por "selfie"?)

\section{Conclusões}

As paredes junto ao chão, o papel a esgarçar-se no rodapé, a madeira que apodreceu. De certa forma, os dois anões de A Boca na Cinza agem como o historiador-trapeiro de Benjamin: duas "criança[s] que brinca[m] com os farrapos do tempo" (Didi-Huberman 2017: 136). Duas crianças que mostram ao mundo a sua desagregação constituinte, as imagens dialéticas em que essa desagregação se dá a ver. 
Porque é na imagem que o ser se desagrega: nela explode e, ao fazê-lo, mostra - mas por tão pouco tempo - do que é feito. A imagem não é a imitação das coisas, mas o intervalo tornado visível, a linha de fractura entre as coisas. Aby Warburg já dizia que a única iconologia interessante, aos seus olhos, era uma «iconologia do intervalo» (Ikonologie des Zwischenraumes). É que a imagem não tem um lugar determinado de uma vez por todas: o seu movimento visa uma desterritorialização generalizada. A imagem pode ser, simultaneamente, material e psíquica, externa e interna, espacial e linguística, morfológica e informe, plástica e descontínua... (idem: 138)

0 intervalo tornado visível, a linha de fratura entre as coisas. 0 intervalo entre um livro de Rui Nunes e um filme de Ali Abbasi, a tensão entre dois objetos que, o mais certo, não se conhecem, que nunca se olharam ao espelho para comparar os tamanhos, para sincronizar gestos, para pôr a língua de fora ou jogar ao sério. 0 intervalo nasce, e depois desenvolve-se, desta colisão que, apesar de involuntária, a princípio, não é depois fortuita. Lê-se um livro. Anos depois, vê-se um filme. E há imagens passadas na leitura que, como relâmpagos, se reacendem anos depois nas imagens de um filme. Como se mesmo a narrativa fílmica mais estruturalmente consensual - com o clássico princípio-meio-e-fim abrigasse, num estado de latência, esses momentos de suspensão, instantes disruptivos ou paralisantes, isso que "não tem um lugar determinado de uma vez por todas" (ibidem). Isso que é, por fim, o fulgor da imagem: o inseto na palma da mão, os despojos da casa no final, o som da neve a ser pisada, Tina distraída de si, não sujeita ao constrangimento - humano, demasiado humano - de ser.

Entre o livro e o filme, o passado continua, portanto, a querer passar. Continua a não querer passar de uma vez só. E eis a sua violência, como sugere Golgona Anghel:

A violência é um intervalo do indizível, é um intervalo da realidade, da natureza, da cidade. É algo que se intersecciona com os poderes, os saberes e os seus dispositivos. Não podemos programá-la. Não é algo que faça parte do foro privado dos poetas e outros videntes de ocasião, muito menos das ferramentas de intervenção dos analistas políticos. A violência exige uma estirpe que sempre existiu: a estirpe dos intrusos, os tártaros que existem em cada um de nós, como potência de um exercício de liberdade, como força de ressignificação. (Anghel 2018: 57-8)

Os intrusos, os tártaros, os bárbaros em cada um de nós - essa procura na própria 
língua de uma língua estrangeira, esse estrangeiro que atravessa o nosso próprio discurso (daí o "movimento de expatriação" pressentido por Eduardo Prado Coelho na escrita de Rui Nunes, cf. Coelho 1997: 285). Esses monstros, trolls ou anões: “Os anões não têm pátria, nem pai nem mãe; somos engendrados por estrangeiros vulgares; a fim de que a nossa raça se perpetue, consentimos em nascer secretamente entre os mais miseráveis" (Lagerkvist 2013: 12). E ainda: "Somos simples hóspedes de passagem. Velhos hóspedes engelhados, cuja visita dura, ininterrupta, há milhares de anos" (idem: 76). E por fim:

Os homens supõem sem razão que é por minha causa que andam inquietos. 0 que na realidade os aterroriza é o anão que se esconde neles, a caricatura humana de rosto simiesco que ergue por vezes a cabeça fora das profundezas do seu ser. Sentem-se tanto mais horrorizados quanto ignoram a sua existência. Espanta-os ver surgir à superfície esse desconhecido que lhes parece nada ter de comum com a sua verdadeira vida. Quando nada aparece acima dos esconsos, sentem a alma em paz. Seguem, de cabeça alta, impassíveis, com rostos lisos, sem expressão. Mas há sempre neles qualquer coisa de diferente, que fingem ignorar; podem viver diversas vidas ao mesmo tempo sem o saber. São estranhamente reservados e incoerentes.

E são disformes, embora isso não seja visível. (idem: 24)

Se o sono da razão gera monstros - essa gravura de Goya cujo título se provara uma atroz profecia, ensinando-nos a citar sem aspas uma infâmia que se tornou comum, com o século XX a abarrotar de corpos gaseados e o nosso tempo com outros tantos corpos a boiar no Mediterrâneo -, se o sono da razão, dizíamos, produz monstros, a deflagração da escrita, e na escrita, em Rui Nunes parece mostrar-nos que mesmo o mais desperto dos homens não se distingue do seu duplo tenebroso. E é nessa indistinção que o medo mais nos assalta: “'um autocarro explodiu na faixa de Gaza, oito mortos, todos crianças': estão iluminados pela luz intermitente do televisor, entre branco e cinzento, bate-lhes na pele a lividez de um plástico translúcido, essa desumanidade” (Nunes 2003: 100). Umas linhas abaixo, e eis este remate incisivo: "São uns poetas, estes repórteres" (ibidem). Poesia e barbárie, o luxo e o lixo. Daí que seja necessário haver alguma raiva contra a literatura para que esta não se deixe deslumbrar pelo seu poder de contar histórias, pelo lustro do papel impresso, pelo programa das festas e condecorações. Uma raiva contra essa "luz intermitente do televisor", 
uma raiva contra todas essas palavras que brilham "com uma luz malevolente". É com essa raiva, e também contra ela, que Rui Nunes escreve. É o seu modo rasteiro de devir outra coisa que não escritor; o seu modo de "fazer batota com a língua" (Barthes 1988: 18) - que é o que para Barthes significa dizer "literatura, escrita ou texto" (ibidem). Assim, às linhas tortas que Deus tem por hábito endireitar, vêm dois anões - e dois trolls - amolgar as arestas bem limadas, sulcar as linhas. E pôr-nos à espera, tensos, no intervalo que se estende entre abrirmos os olhos diante o espelho e, por um brevíssimo instante, arriscarmo-nos a ser surpreendidos por uma cara que nos é estranha. Um risco que é, também, uma forma de coragem: a de sermos contemporâneos, justamente, da (más)cara que temos, recebendo "em pleno rosto o feixe de treva que provém do seu tempo" (Agamben 2010: 23). 


\section{Bibliografia}

Agamben, Giorgio (2010), “O Que É o Contemporâneo?”, in Nudez, tradução de Miguel Serras Pereira, Lisboa, Relógio D’Água, 19-29.

Anghel, Golgona (2018), A Forma Custa Caro - exercícios inconformados, Lisboa, Documenta. Barthes, Roland (1988), Lição, tradução de Ana Mafalda Leite, Lisboa, Edições 70.

Benjamin, Walter (2019), As Passagens de Paris, edição e tradução de João Barrento, Lisboa, Assírio \& Alvim.

Berto, Al (2004), "vêm sôfregos os peixes da madrugada", in Vigílias, seleção e prólogo de José Agostinho Baptista, Lisboa, Assírio \& Alvim.

Caleiro, Maria da Conceição, "Uma plenitude terrível” (entrevista com Rui Nunes), in Cão Celeste, n. 9 4, Lisboa, novembro de 2013, 53-60.

Câmara, Vasco, “Quando os trolls olham para 'o outro': nós” (entrevista com Ali Abassi), in Público, 7 de março de 2019, disponível em https://www.publico.pt/2019/03/07/culturaipsilon/entrevista/naturalmente-dois-trolls1864323 (último acesso em 7/12/2019).

Coelho, Eduardo Prado (1997), "Rui Nunes: qualquer corpo é uma pausa no terror" e "Ter sempre a morte adiada um segundo", in O Cálculo das Sombras, Porto, Asa, 282-291.

de Freitas, Manuel (2012), “Words for the dying”, in Pedacinhos de Ossos, Lisboa, Averno, 115-120.

Deleuze, Gilles / Claire Parnet (2004), Diálogos, tradução de José Gabriel Cunha, Lisboa, Relógio D’Água.

Didi-Huberman, George (2017), Diante do Tempo: História da arte e anacronismo das imagens, tradução de Luís Lima, Lisboa, Orfeu Negro.

Han, Byung-Chul (2018), A Expulsão do Outro - Sociedade, Perceção e Comunicação Hoje, 
tradução de Miguel Serras Pereira, Lisboa, Relógio D’Água.

Lagerkvist, Pär (2013), O Anão, tradução de João Pedro de Andrade, Lisboa, Antígona.

Leroi, Armand Marie (2009), Mutantes - Forma, Variações e Erros do Corpo Humano, tradução de Jorge Lima, Lisboa, Gradiva.

Nancy, Jean-Luc (2000), Corpus, tradução de Tomás Maia, Lisboa, Vega.

Nunes, Rui (2003), A Boca na Cinza, Lisboa, Relógio D’Água.

-- (2018), Suíte e Fúria, Lisboa, Relógio D’Água.

Sloterdijk, Peter (2011), Crítica da Razão Cínica, tradução de Manuel Resende, Lisboa, Relógio D’Água.

Diogo Martins é licenciado em Estudos Portugueses. Em 2015, concluiu o doutoramento em Ciências da Literatura, no ramo da Teoria da Literatura, com um projeto intitulado The greener grass: da autorrepresentação em Alanis Morissette. Em setembro de 2017, iniciou um projeto de pós-doutoramento, financiado pela FCT, no sentido de explorar o autorretrato literário na obra de Rui Nunes. Escreve regularmente sobre livros, filmes e outras linguagens artísticas na revista Vila Nova. 